This item was submitted to Loughborough's Research Repository by the author.

Items in Figshare are protected by copyright, with all rights reserved, unless otherwise indicated.

\title{
The coup that flopped: Facebook as a platform for emotional protest
}

\section{PLEASE CITE THE PUBLISHED VERSION}

http://dx.doi.org/10.5210/fm.v21i1.6333

\section{PUBLISHER}

University of Illinois (@ the authors)

\section{VERSION}

VoR (Version of Record)

\section{PUBLISHER STATEMENT}

This work is made available according to the conditions of the Creative Commons Attribution-NonCommercialShareAlike 4.0 International (CC BY-NC-SA 4.0) licence. Full details of this licence are available at: http://creativecommons.org/licenses/by-nc-sa/4.0/

\section{LICENCE}

CC BY-NC-SA 4.0

\section{REPOSITORY RECORD}

Svelch, Jaroslav, and Vaclav Stetka. 2019. "The Coup That Flopped: Facebook as a Platform for Emotional Protest”. figshare. https://hdl.handle.net/2134/22394. 


\section{$f$ i (8) $s+$ \\ $\mathbf{m} \mathbf{x} \tilde{\mathbf{d}} @ \mathbf{q}$}

PEER-REVIEWED JOURNAL ON THE INTERNET

\begin{tabular}{|c|c|c|c|}
\hline HOME & ABOUT & REGISTER & CURRENT \\
\hline ARCHIVES & ANNOUNCEMENTS & SUBMISSIONS & \\
\hline
\end{tabular}

OPEN JOURNAL

Home > Volume 21, Number 1 - 4 January 2016 > Švelch

Journal Help

f i (3) $s+m \not \tilde{n} \mathbf{d} @ \mathbf{q}$

PEER-REVIEWED JOURNAL ON THE INTERNET

\section{The coup that flopped: Faceboc platform for emotional protest by Jaroslav Švelch and Václav Št}

\begin{abstract}
This paper develops the idea that recent "networked" social movements are driven by emotions and provides an analysis of the role of emotions in movement mobilization. The case study focuses on the 2013 protests against a "coup" within the Czech Social Democratic Party. The protests had an immediate impact, resulting in a series of demonstrations, mainstream media attention and a successful overturning of the "coup". The movement's Facebook page served as an important catalyst for the protest. We argue that the movement's success can be explained by its emphasis on perceived issues of morality. As people tend to gather on Facebook to express their feelings, social media become a primary conduit for emotional protest, which can be subsequently taken to the streets.
\end{abstract}

\section{Contents}

Introduction

(Re)discovering emotions in social movement theory

Finding emotions in online participation studies

Methodology

Dynamics of Facebook mobilization

Emotions and humor in social media discourse

Conclusions

Introduction

In recent years, the use of social media has become common among protest movements in different parts of the world. Facebook, Twitter and blogs played prominent roles in such cases as the Arab Spring, the Occupy movement, the Indignados movement and the Gezi Park protests in Turkey (Castells, 2015). While all of these attracted a diverse following, students and young Internet-connected middle class citizens, for whom using social media is often second nature, comprised a large portion of the protesters (Gerbaudo, 2012; Castells, 2015). These, often emotive and passionate protests, have been put forward as examples of online political participation and a move towards more democratic politics.

Besides the high-profile protests mentioned above, many others took place in different parts of the world, including Central and Eastern Europe. Social media were used extensively during the 2013 uprising in Ukraine against the pro-Russian government of Viktor Yanukovich (Onuch, 2015; Gruzd and Tsyganova, 2015), and the 2013-2014 protests against the Oresharski cabinet in Bulgaria (Ganev, 2014; Tomov and Raycheva, 2015). Other similar protests have taken place in the relatively more stable democracies of the region, such as the 2012-2013 protests against the Slovenian government (Sevignani, et al., 2014).
USER

Username

Password

Remember me Login

JOURNAL

CONTENT

Search

\begin{tabular}{l}
\hline All \\
Search \\
Browse \\
$: \frac{\text { By Issue }}{\text { By Author }}$ \\
$: \frac{\text { By Title }}{\text { Other Journals }}$
\end{tabular}

FONT SIZE

CURRENT ISSUE

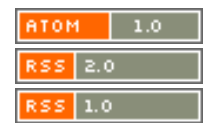

ARTICLE TOOLS

Abstract

Print this

article

Indexing

metadata

E.

item

Supplementary

files

Email this

article (Login required)

Email the

author (Login required)

ABOUT THE

AUTHORS

Jaroslav Švelch

http://svelch.com

Charles University in

Prague

Czech Republic

Department of Media

Studies, lecturer and researcher 
Many of these events took advantage of the possibility to engage supporters at unprecedented speeds via social media. That is also the case of the protest that we will analyze in this paper. On 28 October 2013, hundreds of people gathered at Prague Castle to protest against the latest events in Czech politics. Almost immediately after the Czech Republic's parliamentary elections ended on 26 October 2013, a private meeting between the president - Miloš Zeman - and a group of prominent members of the Czech Social Democratic Party, took place. After the meeting, the group seized control of the party's presidium and asked the party's leader, Bohuslav Sobotka, to step down. Ostensibly, the reason for him to step down lay with the results of the elections - although the party did win the elections, the result of 20.45 percent was relatively disappointing. However, many commenters and citizens interpreted the events as an attempt by the rather divisive president to exert control over the party. A group of activists immediately founded a Facebook page to support Sobotka. The page gathered 5,000 followers in one day and mobilized people to come to the 28 October 2013 demonstration. The protest received prominent coverage in national media, contributing to the pressure on the perpetrators of the "coup" to justify their actions. Two days later, the perpetrators confessed to the meeting with the president, which they had vehemently denied until then, and on 8 November 2013 resigned from their party posts.

As a relatively self-contained and almost immediately successful campaign which started on Facebook, this protest can serve as a suitable case study for research of protest and participation in social media. Much of the existing literature focuses on organizational structures and mobilization potential of online protests (Eltantawy and Wiest, 2011; Kavada, 2014; Aday, et al., 2012). In this study, we argue for a more thorough study of the content of protest communication, namely the role of affect and emotion. As Jasper (1998) points out, social movements tend to be driven by emotional rather than rational concerns. This was especially true of this protest, which channeled moral outrage over the actions of the politicians involved in the "coup". The aim of this article is thus to demonstrate the role of emotions as a catalyst for political protest.

\section{(Re)discovering emotions in social movement theory}

As a subject of study, social media protests occupy the intersection of at least two fields - social movement studies (usually considered a subfield of sociology) and media studies. However, as Cammaerts notes, "the fields of political science and political sociology often have been blind to what media and communication studies have to offer and vice versa $[\ldots]^{\prime \prime}$ [1]. In this paper, we will attempt to integrate the strengths of both of these disciplines.

The sociological study of social movements has flourished since the late 1960 s protests. Initially, this was a reaction to previous conceptualizations of crowds, which emphasized their irrational mob behavior (Le Bon, 2001). In the 1960 s, movements started to be viewed instead as purposive and following rational agendas (Della Porta and Diani, 2006). A number of approaches towards the topic emerged focusing on resource mobilization or the structural conditions leading to the emergence of social movements. Since the 1980 s, theories of framing have been used extensively to study the ways in which social movements articulate their goals and mobilize supporters. According to Snow, et al. (1986), frames are schemata of interpretation which render events meaningful and help guide collective action. However, these schemata were seen as cognitive and rational rather than emotional. There was little space for research into emotion in the 1970s-1990s period. According to Goodwin, et al. (2001), emotions have led "a shadow existence for the last three decades, with no place in the rationalistic, structural, and organizational models that dominate academic political analysis" [2]

Recent protests have attracted considerable interest among social movement studies. In the tradition of resource mobilization theory, studies about these events focused on the role of digital media as tools that help organize protests and gain sympathizers (Aday, et al., 2010; Eltantawy and Wiest, 2011; Kavada, 2013; Bennett, et al., 2014; Aslan, 2015).

However, the focus on pragmatic and organizational uses of social media often obscures the role of emotions. According to Jasper (1998), both negative (fear, outrage, or shame) and positive (trust, loyalty, or hope) emotions are central to social movements, and without emotions, there might be "no social action at all" []ㅡ. Instead of dismissing emotions as irrational and dangerous (as was the case in the early sociology of the crowd), he sees them as powerful motivators, which explain both momentary action and continued allegiance (Jasper, 2011). As we will see later, emotions are especially important in contemporary protests which tend to unfold quickly and hardly allow for long-term strategic planning.
Václav Štětka http://polcore.cz

Charles University in Prague

Czech Republic

Department of Media Studies, senior researcher 


\section{Finding emotions in online participation studies}

In media studies, political and societal struggles are interpreted as acts of mediated communication, and the recent protest movements are usually seen as examples of media participation. Following Carpentier (2011), we can understand participation as an activity that allows one to take part in communication in a meaningful, empowering way. The introduction of social media has raised the question whether these media technologies are more conducive to a form of participation which can effect change in real politics (Casteltrione, 2015). According to the normalization thesis, digital media merely reinforce existing inequalities within society in terms of political engagement (Norris, 2000; Weber, et al., 2003). Other scholars are cautiously optimistic and argue that social media can in fact mobilize specific groups of citizens (Boulianne, 2011; Enjolras, et al., 2012; Štětka and Mazák, 2014; Jones, 2015). However, yet another line of thinking dismisses the use of social media for political mobilization as slacktivism, described as casual online behavior with limited real life impact (Morozov, 2009; see Christensen, 2011).

Recent protest movements seem to be fitting test cases for these questions. The initial reaction of the Western press to the Arab Spring suggested that it was a "Facebook revolution" (Bashri, et al., 2012), while critics of this notion argued that the role of social media was "fetishized" [4]. More measured analyses appeared later, concluding that social media did not in fact cause the events (Aday, et al., 2012; Harlow, 2013; Khondker, 2011), but rather "accelerated change by facilitating, encouraging and prompting mobilization" [ㅁ].

While the debate on social media effects is still open, it is the actual process of mobilization which we will examine in this paper. Such investigation requires a more nuanced understanding of both technological features of social media and its relationship to content that protest movements circulate. Regarding the former, we can use the concept of affordances, which media studies borrowed from design theory (boyd, 2011). Gaver defines affordances as "properties of the world that are compatible with and relevant for people's interactions" []]. The properties of social media afford their users to post and share content (including images and video) instantaneously, to comment or offer "likes" to existing content, or to create "events", which people may "join", signaling their intention to participate.

The affordances of social media have made them a relatively low-barrier means of communication and organization. People routinely use them for various personal and practical reasons, as well as for political purposes and may seamlessly move between any of these modes of communication (Jenkins, 2006). Empirical studies have shown that the use of social media is driven by emotional needs (Wang, et al., 2012) and that people use them for entertainment and affective communication (Quan-Haase and Young, 2010; Smock, et al., 2011; Alhabash, et al., 2014). Chakrabarti and Berthon (2012) argue that social media can amplify both negative and positive emotions []].

Despite the pervasiveness of emotional communication, research into online political participation has been largely informed by the Habermasian ideal of the public sphere (Habermas, 1989) and thus focused on the use of digital media for rational deliberation (Lewinski, 2010; Ruiz, et al., 2011; Weber, 2014; Wright and Street, 2007). According to Dahlgren (2005), "the rationalist bias tends to discount a wide array of communicative modes that can be of importance for democracy, including the affective, the poetic, the humorous, the ironic, and so forth." [] Several recent studies of protest discourses have shown that much of their content is personal, informal, emotional or humorous (Harlow, 2013; Jungherr, 2012; Milner, 2013; Peck, 2014).

Social movement theory has also begun to accept emotion as an important driver of protest and participation. This tendency can be demonstrated by Gerbaudo's work on the multiple protest movements of 2011 (Arab Spring, the "indignados" movement, and Occupy Wall Street). Drawing from Jasper, he claims: "Facebook messages, tweets and blog posts have constituted not simply channels of information but also crucial emotional conduits through which organisers have condensed individual sentiments of indignation, anger, pride and a sense of shared victimhood and transformed them into political passions driving the process of mobilisation." []ㅡ Castells also speaks of spontaneous networked movements "triggered by a spark of indignation [...] or a peak of disgust with the actions of the rulers." [1이

In line with Gerbaudo's work, this article will investigate how emotional narratives made people come together, first online, and then in the streets. While Gerbaudo's analysis drew from interviews with protesters and activists, our case study focuses on the contributions by the movement's supporters.

\section{Methodology}

The main questions that have driven this case study are in summary:

"How was emotional discourse deployed by both the protest leaders and 
ordinary supporters of the protest, and how did it relate to the dynamics of mobilization?" In addition, we will take into account the role of humor, and mainstream media coverage of the protests.

We draw conceptual and methodological inspiration from previous discussions of framing and emotions (Goodwin, et al., 2001; Kemper, 2001). Jasper proposes to study emotions in social movements similarly to how more cognitive cultural meanings - such as the goals or values of a movement - are examined, i.e., to analyze their expressions in discourse (Jasper, 1998). Goodwin and Jasper suggest including emotions in the otherwise cognitively oriented framing theory and to apply the resulting combination to social movements (Goodwin, et al., 2001). We can therefore see emotions as framing devices, in a fashion similar to existing studies of diverse types of movements, including animal rights activism (Groves, 2001) or the anti-consumerist Adbusters foundation (Wettergren, 2005).

Our study takes a mixed-method approach and focuses on one specific protest as it unfolded between 27 October 2013 and 8 November 2013. Our primary material is the content of the Facebook page "I want Bohuslav Sobotka, not Michal Hašek", collected using the Scrapbook extension for Mozilla Firefox. Later on, we mined for formatted data using the Netvizz application for Facebook (Rieder, 2013). Overall, we collected 85 posts by page administrators ("posts by page"), 860 posts by users ("posts by others") and 2,216 comments and replies. For qualitative analysis, we built a smaller corpus of 300 posts and comments, taking into account the impact of the selected items, as well as diversity of the corpus [11].

To provide a general overview of the development of the protest in the online environment, we gathered basic metrics from the page, including numbers of posts and comments per day. In addition, we have conducted a frequency analysis of the news articles/items about the "coup" in the Czech media during the same period (27 October 2013 - 8 November 2013), using the keywords "Sobotka" and "Hašek"; the search resulted in the total of 2,703 news items for the two weeks observed [12].

In the qualitative part of our research, we first established categories of messages posted by page administrators, following the typology developed by Hinsley and Lee (2015). Then, we went on to analyze framing processes at play, using the concepts developed by Snow, et al. (1986), namely frame bridging, which involves linkage of a movement with "unmobilized sentiment pools or public opinion clusters." [13]. The central component of our analysis was the identification and interpretation of emotions expressed by protest supporters. Here, we drew from Jasper's (1998) inventory of emotions, paying special attention to moral emotions, as "emotions most directly connected to moral sensibilities [...] are especially pervasive as motivators of action." [14] We identified emotions in user posts, based on their explicit expression or on the loaded vocabulary utilized by the users. While not everyone openly expresses their emotions in online environments, we can suppose that people who "like" the items share the emotional attitude expressed, at least to some extent.

Inspired by Wettergren's research which combined analysis of emotions and irony, we focused not only on (seemingly) earnest emotional expressions, but also on irony and humor, including image memes (Harlow, 2013; Milner, 2013; Shifman, 2011).

To incorporate the views of the page administrators, we conducted an email interview with the spokesman of the movement, Martin Vrba. All material in this case study is originally in Czech and all quotes were translated into English by the authors.

\section{Dynamics of Facebook mobilization}

Before we start analyzing the emotions at play on the Facebook page, it is necessary to describe the dynamics of the protest and the way it unfolded over the short course of 13 days. As we mentioned above, the election into the Chamber of Deputies of the Czech Parliament generally regarded as the country's most important elections - had closed on Saturday, 26 October 2013 at $2 \mathrm{pm}$. The definitive results were announced by Saturday evening: Social Democrats led by Bohuslav Sobotka received 20.45 percent votes, followed by the new centristpopulist party ANO 2011, which gathered 18.65 percent and was hailed as the true "winner" of the elections.

The same evening, a meeting took place between the president Zeman who had had a strained relationship with Sobotka - and a prominent group of Zeman's supporters from the Social Democratic Party, including one of the party's vice-chairs Michal Hašek, Sobotka's long-standing rival [15]. The next day at the party's presidium meeting, Hašek's group took control of the presidium, and passed a resolution which asked Sobotka to step down as Chairman. Sobotka's supporters considered this maneuver an illegitimate "coup" organized with the help of a third party, the president Zeman. In their eyes, Zeman saw a chance to help his ally Hašek rather than Sobotka, become the next prime minister. 
The following day, a group of activists launched the Facebook page called "I Want Bohuslav Sobotka, not Michal Hašek" (IWBS). The group included contributors of the left-wing online news outlet Deník Referendum [16], and members of the progressive left-wing activist groups Idealisté.cz and Generace $Z$ [17]. According to the spokesman of the initiative, Martin Vrba, it was not a partisan effort. "The group came together around the belief that were the 'coup' to be successful, progressive elements of the Socialist Democratic politics would suppressed - and furthermore it would be done in a way that does not fit into democratic politics." (Vrba, 2015) As Vrba confirmed, Sobotka himself was not involved in the initiative.

The first post on the page dates from 27 October 2013, 8:30pm. An hour later, the administrators announced a demonstration, which was to take place on Monday evening, and created a Facebook event for it. By $11: 39 \mathrm{pm}$, the page boasted more than 1,000 likes, and more than 100 people confirmed their participation in the demonstration. The Monday demonstration was attended by hundreds [18] of people, including some notable Sobotka supporters from the Social Democratic party. By Monday night, the page reported over 5,000 likes, a high number given that the party's own official Facebook page had only about twice as many likes at the time (Štětka, 2014). Figure 1 shows the development of page likes in the week following the foundation of the Web site.

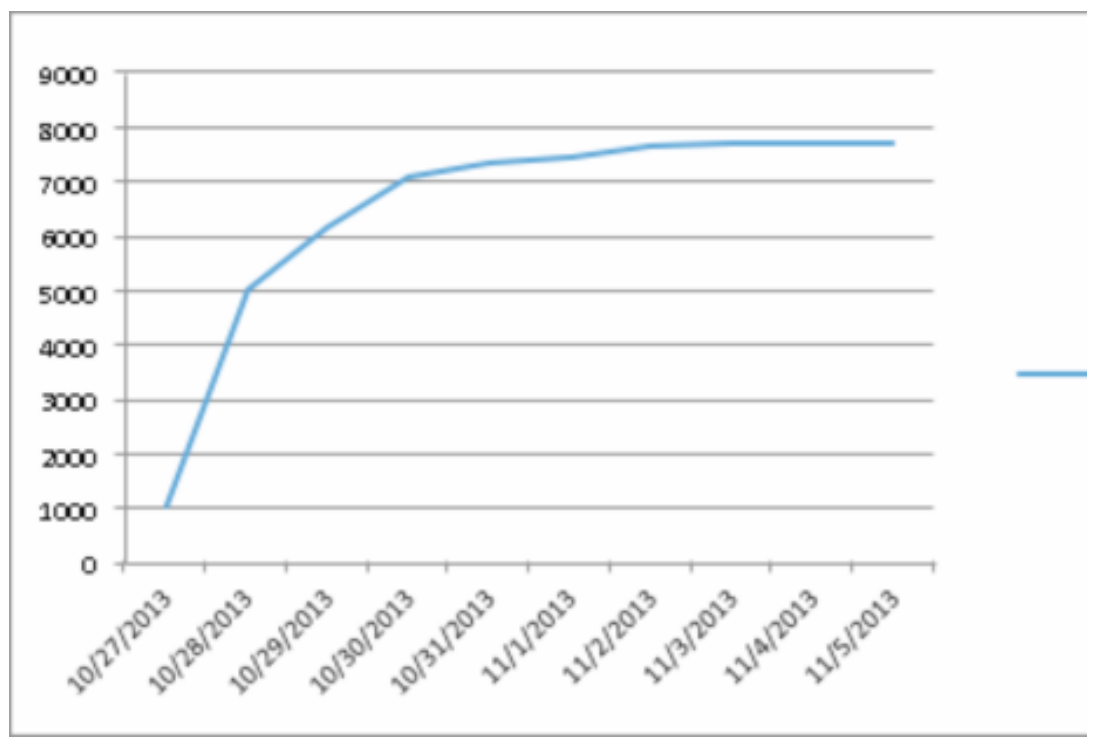

Figure 1: Development of page likes over the course of the protests. Sourc

The demonstration, as well as the initiative itself, attracted significant media coverage in all major daily papers and TV newscasts. At the same time, news media continued to follow the actors of the meeting closely and investigated the circumstances of the "coup". On Tuesday, 29 October 2013, the Czech public service television conducted a live studio interview with Michal Hašek, who denied taking part in the secret meeting. Some hours later, one of the other attendants of the alleged meeting confessed to taking part in it. On 30 October 2013, another demonstration supporting Sobotka took place in Brno - the second largest Czech city and was attended by around 500 people. Over the course of the day, it became clear that Hašek could no longer defend himself. His claims had been publicly exposed as untruthful, and he was losing the support of both the public and party members. Later that day, he admitted that he did in fact participate in the meeting with president Zeman. This marked the beginning of his downfall. According to a post-election poll $(N=$ 1,272) conducted between 2 November 2013 and 6 November 2013, only five percent respondents expressed support for Hašek, while 57 percent supported Sobotka (Focus, 2013). On 8 November 2013, Hašek and two other coup perpetrators resigned from their party posts. 


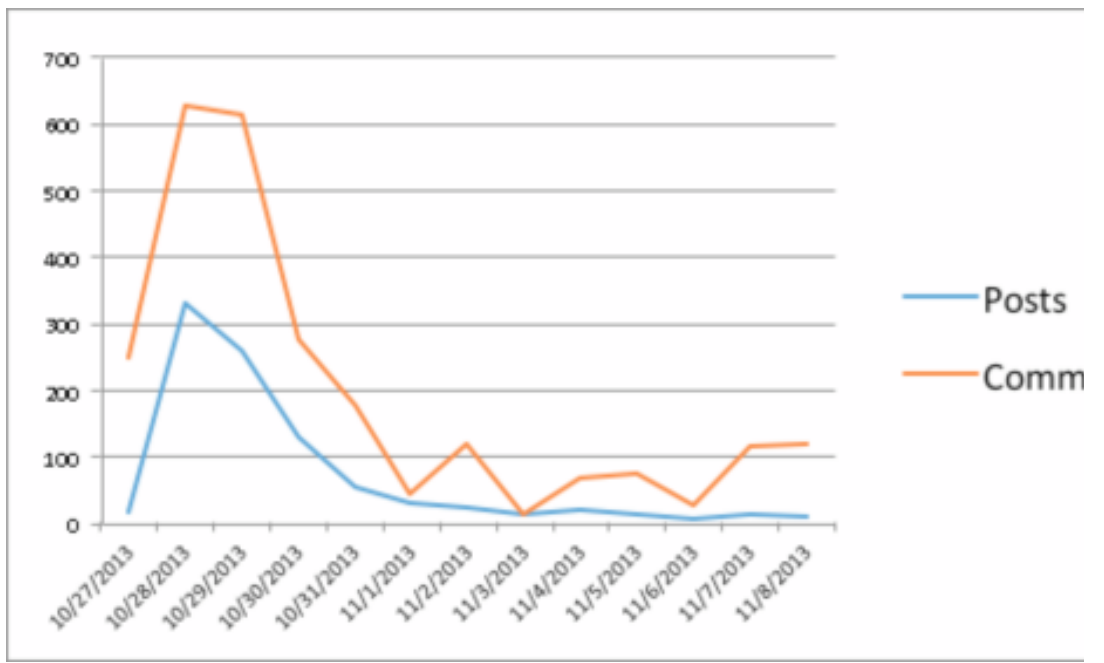

Figure 2: Development of Facebook engagement over the course of the prote both those by page and those by users. Source: Authors' dat

If we look at the data from IWBS Facebook page more closely, we can see that the page attracted most likes and most traffic in the period that immediately followed the coup. On Figure 1, we can see that the page gained more than half of its "likes" on 28 October 2013, the day of the first demonstration. Fiqure 2 shows the dynamics of the activity on the IWBS Facebook page. The number of posts (both by administrators and users), as well as the number of comments and replies to these posts also peaked on the day of the first demonstration (28 October 2013), stayed high the next day, but fell dramatically when the tides started to turn and Hašek confessed. Based on this development, we can argue that the initial surge of activity resulted primarily from an immediate response to the "coup".

Press coverage followed a similar pattern, although delayed by one day. Figure 3 shows that on 28 October 2013, one could observe only negligible increase of the number of news items, but a rapid surge in Facebook engagement. The attention of the press peaked on 29 October 2013 - the day following the Prague demonstration - and started falling the day after Hašek's confession. In the initial stages of the protest, quantitative changes in Facebook activity therefore preceded, rather than followed, the reporting by professional news media. Although no causal relationship should be implied, the comparison suggests that the scale of Facebook users' mobilization cannot be explained solely as a reaction to news media, but that it had a life of its own. This illustrates the immediate appeal of the Facebook page which attracted citizen and activist voices mere hours after the "coup".

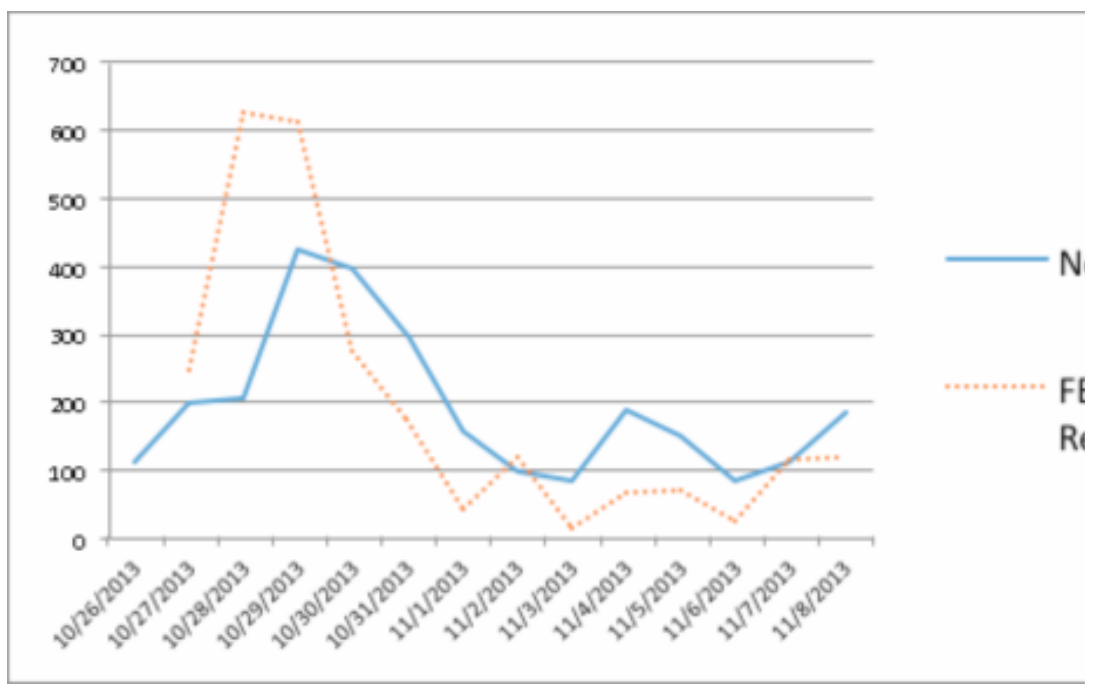

Figure 3: The development of the number of news items about the coup publis all mainstream news outlets tracked by the Newton Media database, including $\mathrm{W}$ TV news. For comparison, the dotted line shows the combined number of comn the IWBS Facebook page. Source: Authors' data. 
In the following sections, we will focus on the content of the communication on the IWBS Facebook pages to show how the immediate attraction of the movement was related to the fact that the events - and the way they were portrayed by page administrators - appealed to emotions rather than partisanship.

\section{Emotions and humor in social media discourse}

The conversation on the IWBS Facebook page has been, to a large extent, controlled by the page's administrators [19]. Their posts received hundreds of "likes" (with an average of 140.47) and dozens of comments (on average 25.61). The administrators had the opportunity to mobilize support, as well as set a tone of the discussion. Based on Hinsley and Lee's (2015) typology, we have identified five types of posts. In our material, the administrators (1) mobilize users to spread the message, share the link to the page, or to write e-mail messages to members of the Social Democratic Party; (2) bring news about the progress of the initiative, including press coverage; (3) share statements of support from public personalities, party members and the party's local organizations. The admins also posted (4) expressive and emotive evaluations of the actors and events; and (5) humorous reactions to the events, mostly making jokes about the perpetrators of the coup. More than one strategy was often employed within the same post. As we suggested above, our analysis will focus mainly on the latter two categories.

In terms of formal properties, many posts consist of plain text or links to existing news articles. However, among the page's best "liked" and most memorable pieces of content are images which contain black and white portraits of the politicians involved on orange background (orange being the brand color of Czech Social Democrats), and a mobilizing or expressive message.

Given the title of the Facebook page, it is not surprising that user contributions in our corpus were overwhelmingly supportive, although some dissent was present, especially among the few user posts which attracted a small number of likes, but a relatively higher comment count [20] .

Despite setting the tone of the debate, IWBS administrators never mentioned their names or political allegiances in their posts, preferring to become "soft leaders" who set the scene and create an outlet for participation (Gerbaudo, 2012). They also refrained from explicitly promoting their own left-wing progressive agenda. This was likely to contribute to the wide appeal of the movement, which seemed unconnected to any existing political entity, but rather presented itself as an ad hoc reaction to a specific political - and moral - event.

Channeling moral emotions: Beyond party politics

From the very beginning, the administrators and sympathizers alike framed the protest as something that reached far beyond party politics. They portrayed president Zeman's interference as well as Hašek's unscrupulous attempt to wrest control from Sobotka as undemocratic, unfair, and - most importantly - morally repugnant. We will illustrate this with a qualitative probe of the discourse which unfolded.

According to Vrba (2015), IWBS did not "frame the narrative as an internal matter of the Social Democratic Party, but as a struggle for the democratic nature of the partisan system as such." This struggle was portrayed in emotional terms. The very first post by the page administrators stated: "Bohuslav Sobotka must not bend before the pressure of Zeman's fifth column in the Czech Social Democratic Party. We want Bohuslav Sobotka as prime minister, not Michal Hašek, and we ask the leaders of Czech Social Democratic Party to support him." The word coup was used on the page for the very first time an hour later in a user comment which said: "This is an appalling coup!" The next day, it was also adopted by the page admins [21].

In the first two days of the campaign, IWBS called Hašek and his companions "mafia" and used the expression "betrayal from Prague Castle", the Castle being the seat of the President. The activists framed the coup as a moral failure and a threat to democracy rather than a threat to progressive left-wing politics. As moral sensibilities are more commonly shared than political allegiances, this kind of framing can be seen as a successful example of frame bridging.

The moral tone of the discourse intensified when it was revealed that Hašek attempted to cover up the alleged meeting. The revelation contributed to frame amplification by removing potential ambiguity (see Snow, et al., 1986) and reinforcing the definition of the "coup" as a morality issue. The two most popular images posted by IWBS administrators both focused on this fact. The first one (754 likes) showed the faces of the "traitors" and said "We do not want liars amongst us!" The second one (617 likes) contained Hašek's portrait and the following message: "Michal Hašek, you are not only a traitor, but also a LIAR in front of the whole nation. We demand that you step down from all of your party posts and suspend your membership in the party." 


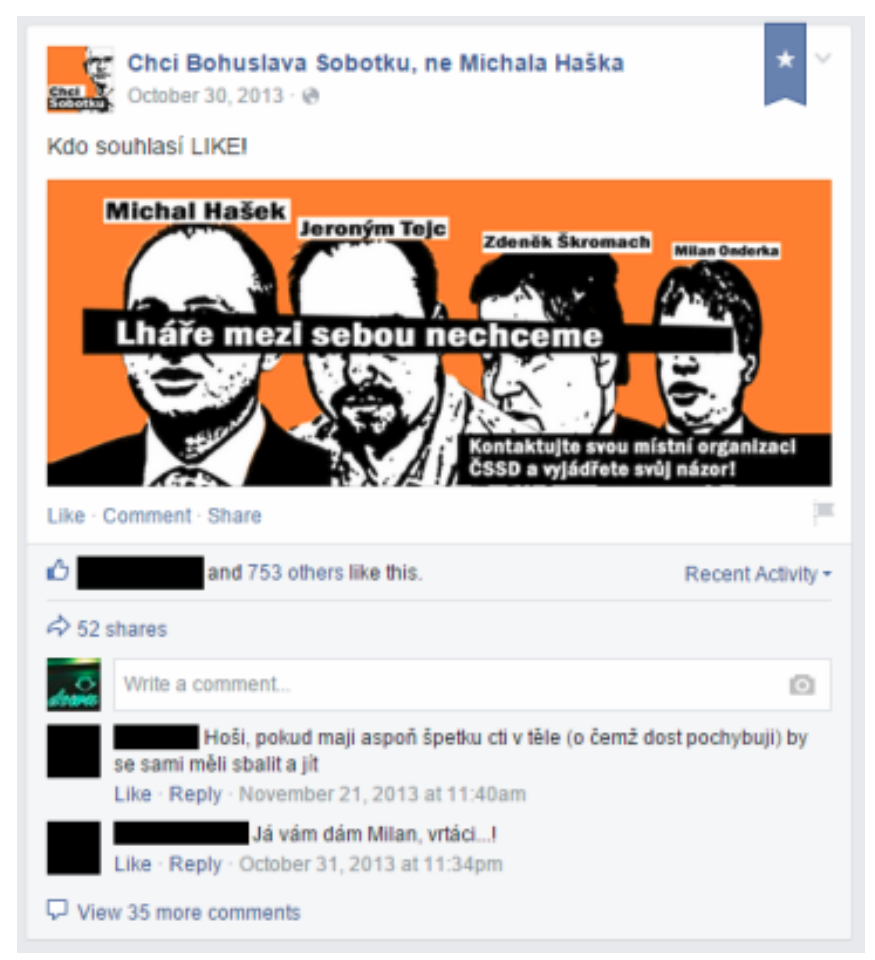

Figure 4: Screenshot of the most "liked" post by IWBS. Besides the names of some of the coup perpetrators, the image reads: "We do not want liars amongst us! Contact your local Social Democratic office and express your opinion." The caption translates as: "If you agree, LIKE this!"

The moral dimension of the events, along with the perception that democratic processes might be failing, attracted a number of sympathizers who would usually not support or vote for Social Democracts. In 17 out of the 215 posts or comments by users in our corpus (7.91 percent), the authors explicitly stated they did not vote for the party, but supported Sobotka against Hašek nonetheless - and we can assume that more users held that opinion privately. Five out of eight most liked comments in the corpus make an argument similar to this one: "I didn't vote for Social Democrats, but I'll happily support Sobotka against the filth that is going on."

If we read the corpus through the lens of Jasper's typology of protest emotions, we can see that the events triggered intense, and often deeply personal, emotional reactions in many of the users, who did not hesitate to express them. Five political emotions featured prominently among user responses, all of them closely tied to moral sensibilities - outrage, shame, indignation, and sympathy (Jasper, 1998).

Being a negative short-term emotion, outrage is at its most palpable in the posts and comments which include emotionally loaded vocabulary and explicit descriptions of one's immediate feelings. The users say that the events are "disgusting" and make them want to "puke"; they call the conspirators Zeman's "bootlickers" and "swines". The third most liked user comment (95 likes) exclaims: "Not to support Sobotka is a murder of all decent Social Democrat voters."

The emotion of shame is brought up by both page administrators and users. The former invite their audience to "support politics that you don't have to be ashamed of". The latter admit they feel ashamed for the cities where "traitors" came from or for the political representation of their country: "I have rarely felt more ashamed for my city than after reading this headline". Another commenter says: "I am ashamed for my president. I am ashamed to be a Social Democratic voter. [...] Please, Mr. Sobotka, keep on fighting, so that I don't have to be ashamed for you as well. Thanks." Other people expressed their indignation over being cheated: "Bohuslav Sobotka should lead this government. As a voter, I feel cheated." Expressions of positive emotions, though present, attracted relatively less attention that the negative ones. They tended to frame Sobotka as a victim of betrayal. Users voiced their sympathy for him by saying that they would "root for him" and wished him strength. The administrators also took advantage or more long-term loyalties and animosities of people by pitting Sobotka against the controversial figure of President Zeman. One of the mobilization messages made it clear: "Come to Prague Castle today and show Zeman and his minions [...] that democratic principles are worth more than toilet paper!" 
Overall, we can see that the IWBS Facebook page became a conduit for disgruntled citizens to share their immediate emotional reactions to the attempted "coup". The frame of "betrayal" and "coup", suggested in a rather neutral language by the page administrators, was amplified by individual users, who did not shy away from much stronger language. The discourse which unfolded on the Facebook pages was then brought into the streets, where people showed up with banners referring to "coup", "betrayal" and "liars".

\section{Photoshopped images as playful protest}

Besides emotions, humor is also a frequent mode of political discourse and an understudied means of political protest. As Jenkins, Milner and other scholars have observed, user-generated Internet memes, which start to circulate in response to significant public events, can be considered a form of vernacular and populist political expression, as well as online participation (Highfield, 2015; Jenkins, 2006; Jungherr, 2012; Milner, 2013).

We extracted 39 items from comments and user posts on the IWBS Facebook pages, most of which were image-based, two being videos and one a simple computer game. In terms of their formal properties, they ranged from crude to professional-looking; in terms of content, they ranged from pictures of pigs with the faces of the coup perpetrators to witty and unexpected juxtapositions. The early ones mostly commented on the nature of betrayal and portrayed Hašek and his co-conspirators as turncloaks in league with the president Zeman.

The game SoBoHaZem Invaders was published on 28 October 2013. A simple clone of Space Invaders, it pitted the player-controlled Sobotka against swarms of aliens represented by portraits of the conspirators Roman Onderka, Michal Hašek, and, on the final level, Miloš Zeman. While the game hardly made a sophisticated argument about party politics, it proved the willingness of the author to engage with and entertain the online public with a topical computational artifact.

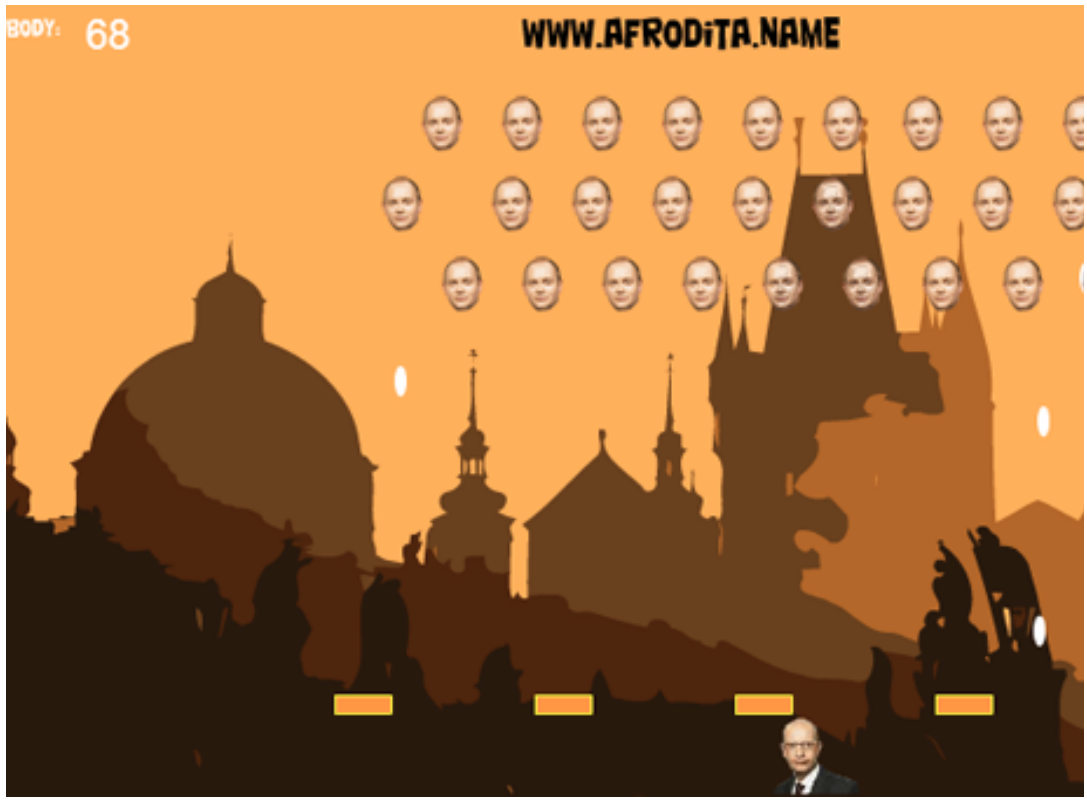

Figure 5: The SoBoHaZem Invaders online game. Sobotka shooting Hašek-hea Prague Castle.

Thanks to its unambiguously embarrassing nature, the revelation of Hašek's fabrication inspired people to create several popular images. The most liked user comment (113 likes) on the IWBS Facebook page was a photoshopped image of Hašek as a schoolboy who diligently raises his hands when asked "Is there anybody here who is certain he wasn't at Zeman's place on Saturday?" In addition to a remix of a popular Czech children's comics, the coup even generated a variation on the "Downfall" video meme (Cheezburger, Inc., 2013), which shows Adolf Hitler losing his temper after hearing that Hašek confessed to his participation in the meeting.

As people tend to use Facebook as a source of entertainment, circulation of coup-related Internet memes can be seen as evidence of popular participation. In this case, enough artifacts were produced and shared to warrant news articles on major online news sites which collected them while praising the creativity of Internet users (Vítková, 2013; Smíchov, 2013). This online ridicule of Hašek foreshadowed the public opinion polls which showed minimal support for his faction. 


\section{Conclusions}

According to the IWBS spokesman Martin Vrba, the members of the movement "believe that the activities organized through the page made a significant contribution to the balance of power inside the Social Democratic party during the faction struggle which was going on at the time." (Vrba, 2015) But as in all protest movements, it is extremely difficult to estimate the impact of the social media campaign. The failure of the coup can be attributed to several factors - among them the media who investigated the coup and provided evidence that Hašek was not speaking the truth, the internal struggles within the Social Democratic party, and the public condemnation of Hašek channeled by social media. All of these three developments influenced and fueled each other. It is unlikely that Facebook page alone would have brought Hašek down. However, it was the primary and most up-to-date communication channel of the protest organizers. As Vrba puts it, "the Facebook page proved to be a really effective method of mobilizing the largest amount of people in a shortest time period, in order not to waste the 'momentum' of the situation." (Vrba, 2015)

The lightning-fast mobilization of hundreds of people, which can be observed in our quantitative data, served as a proof that Sobotka had considerable public support and did so even before post-election polls could be conducted. The page also managed to gain support among party members and the media, posting names of party members who stood up against the coup, as well as links to news articles reporting on or supporting their cause. Traditional categories of political participation, like contacting MPs, were conducted alongside newer ones - contacting representatives became especially widespread thanks to a list of e-mail addresses of Social Democratic MPs that circulated among Sobotka's supporters and was repeatedly posted on the page.

In our analysis of the protest, we connected the timeliness of the protests with their emotional nature. When the moral frame was in place, proSobotka activists did not have to spend extra effort persuading potential sympathizers to adopt their outlook. Users themselves concentrated on the issues of morals, decency and betrayal - "common denominators" that could bring together a diverse array of supporters, including die-hard Social Democrats, voters of other parties or people who simply dislike president Zeman. The Facebook page catalyzed the protest by offering a space where all of these people could vent their emotions, by expressing them both earnestly and jokingly. The movement then streamlined the accumulated emotions into a protest that mattered in the eyes of the media and politicians. Physical presence in the streets - or at Prague Castle, in our case - as well as direct messages to politicians constituted definitive and resolute demonstrations of the movement's power. As Vrba pointed out, movement organizers considered their presence at demonstrations "natural" (Vrba, 2015). Only a small minority of Facebook supporters attended these demonstrations, but we cannot dismiss the rest as mere "slacktivists" (Morozov, 2009). By liking the page and/or sharing their opinions and emotions, each user contributed to the visibility, acceptance and impact of the movement. The large number of page likes was used as a marker of success by page administrators and evoked a sense of solidarity among protest sympathizers. At the same time, the online support displayed by Sobotka's supporters was followed and reflected by the mainstream news media, further promoting and accentuating the political agenda of the protesters.

Overall, the case has illustrated the potential of Facebook as a platform for emotional protest. It indicated that both its technological affordances and usage conventions make it relatively easy for users to instantaneously share emotive responses and jokes about politics, and facilitate fast growth of online protest movements. Along with Gerbaudo, we can claim that "these forms of communication have contributed in creating a contagious sense of anticipation or impetus in advance of the protests." [22] At the same time, supporters of the pro-Sobotka movement did not express their allegiance to a well-established movement, but rather to a single powerful message about a particular event which has unleashed an outpour of emotions. This also seems to be the case in many other recent examples of online protests, such as the Gezi Park protests or Slovenian protestivals (Sevignani, et al., 2014; Kavada, 2014). The protest did not turn into an ongoing campaign when the tides started to turn and victory seemed to be guaranteed, Facebook activity started to wane. Throughout the protest's duration, the administrators exposed neither themselves nor their political agenda. We can therefore see the protest as a confirmation of Poell and van Dijck's (2015) thesis that the architecture of Facebook supports "event-oriented" activism.

In our paper, we wanted to demonstrate the need to study online protest not only in terms of organization, but also in terms of affect and humor. We can only begin to understand the dynamics of Facebook protest when we take a close look at the content of the messages posted - and these tend to be laced with emotions and humor. The ongoing emphasis on the study of deliberation and organization overshadows the role emotions play in online protest. Emotions of online protest therefore need to be 
demystified by scholarly work. In our Czech case, the capacity for emotional protest was used to support a movement which promoted democratic participation. In other cases, such as the recent marches against immigration into the European Union, emotions and fearmongering are being used by much more problematic populist and extremist movements. Gaining a deeper understanding of online emotional protest is essential in order to understand both kinds of movements. FM

\section{About the authors}

Jaroslav Švelch is a lecturer and researcher at the Charles University in Prague's Faculty of Social Sciences. He was a Microsoft Research New England Ph.D. intern in 2012. His work focuses on local histories of computer games, social uses of digital technologies, humor in virtual spaces, online language management, and the concepts of monstrosity and adversity in games.

E-mail: jaroslav [at] svelch [dot] com

Václav Štětka is a senior researcher and leader of the PolCoRe research group at the Faculty of Social Sciences, Charles University in Prague. His research interests encompass political communication and new media, transformation of media systems, and issues of media ownership and globalization.

E-mail: vaclav [dot] stetka [at] fsv [dot] cuni [dot] cz

\section{Acknowledgments}

This research was supported by the Czech Science Foundation (GAČR), Standard Grant number 14-05575S - "The role of social media in the transformation of political communication and citizen participation in the Czech Republic".

\section{Notes}

1. Cammaerts, et al., 2013, p. 3.

2. Goodwin, et al., 2001, p. 3.

3. Jasper, 1998, p. 398.

4. Gerbaudo, 2012, p. 5.

5. Harlow, 2013, p. 73.

6. Gaver, 1991, p. 79.

7. Chakrabarti and Berthon, 2012, p. 160.

8. Dahlgren, 2005, p. 156.

9. Gerbaudo, 2012, p. 14.

10. Castells, 2015, p. 252.

11. Given their prominence on the page and their relatively low number, we included all 85 posts by page. To include the voices of the users, we added 133 most liked comments and replies (10 likes and more), as well as 82 posts by users which ranked among the 50 most liked (more than four likes) or commented ones (more than two comments). In our corpus, posts by page are the most prominently featured items with most user feedback (an average of 140.47 likes per post). The average number of likes per "posts by others" was 1.23 , while an average comment got 2.40 likes.

12. The search was conducted using the database of the company Newton Media (http://www.newtonmedia.cz) and was restricted to all relevant nationwide news media, that is national dailies, television and radio stations, economic and political magazines and Internet news servers.

13. Snow, et al., 1986, p. 467.

14. Goodwin, et al., 2001, p. 10.

15. It is important to note that President Zeman himself is a former chairman of the Social Democrats, but quit the party acrimoniously in 2007.

16. Available online at http://www.denikreferendum.cz.

17. Idealisté.cz ("Idealists.cz" in English) is a progressive activist organization, originally a section of the Czech Young Social Democrats, later an independent body. Generace Z (or "Generation Z") is a group of left-wing intellectuals, mainly students from the city of Brno.

18. Two of the news outlets reported "hundreds" of people, while page administrators posted that 2,000 people took part. 
19. According to Vrba, four to five people acted as the page's admins.

20. One of the dissenting posts reads: "Sobotka has led the Left to defeat. [...] He is a smiling coward. [...] We need to get rid of this weakling."

21. Both fifth column and coup are words that resonate with political sensibilities of many Czech citizens, due to their connotations with World War II and the February 1948 coup orchestrated by the Communist party. Incidentally, the first Prague demonstration took place on 28 October 2013, the anniversary of Czechoslovak independence and a national holiday, providing another reference to history and tradition.

22. Gerbaudo, 2012, p. 161.

\section{References}

Sean Aday, Henry Farrell, Marc Lynch, John Sides and Deen Freelon, 2012. Blogs and bullets II: New media and conflict after the Arab Spring. Washington, D.C.: U.S. Institute of Peace, at http://www.usip.org/sites/default/files/PW80.pdf, accessed 1 January 2016.

Sean Aday, Henry Farrell, Marc Lynch, John Sides John, John Kelly and Ethan Zuckerman, 2010. Blogs and bullets: New media in contentious politics. Washington, D.C.: U.S. Institute of Peace, at http://www.usip.org/sites/default/files/pw65.pdf, accessed 1 January 2015.

Saleem Alhabash, Yi-hsuan Chiang and Kanni Huang, 2014. "MAM \& U\&G in Taiwan: Differences in the uses and gratifications of Facebook as a function of motivational reactivity," Computers in Human Behavior, volume 35 , pp. 423-430. doi: http://dx.doi.org/10.1016/i.chb.2014.03.033, accessed 1 January 2016.

Billur Aslan, 2015. "The mobilization process of Syria's activists: The symbiotic relationship between the use of information and communication technologies and the political culture," International Journal of Communication, volume 9 , pp. 2,507-2,525, at http://ijoc.org/index.php/ijoc/article/view/3527, accessed 1 January 2016.

Maha Bashri, Sara Netzley and Amy Greiner, 2012. "Facebook revolutions: Transitions in the Arab world, transitions in media coverage? A comparative analysis of CNN and Al Jazeera Englishs online coverage of the Tunisian and Egyptian revolutions," Journal of Arab \& Muslim Media Research, volume 5, number 1, pp. 19-29. doi: http://dx.doi.org/10.1386/jammr.5.1.19 1, accessed 1 January 2016.

W. Lance Bennett, Alexandra Segerberg and Shawn Walker, 2014. "Organization in the crowd: Peer production in large-scale networked protests," Information, Communication \& Society, volume 17, number 2, pp. 232-260.

doi: http://dx.doi.org/10.1080/1369118X.2013.870379, accessed 1 January 2016.

Shelley Boulianne, 2011. "Stimulating or reinforcing political interest: Using panel data to examine reciprocal effects between news media and political interest," Political Communication, volume 28, number 2, pp. $147-162$.

doi: http://dx.doi.org/10.1080/10584609.2010.540305, accessed 1 January 2016.

danah boyd, 2011. "Social network sites as networked publics: Affordances, dynamics, and implications," In: Zizi Papacharissi (editor). A networked self: identity, community and culture on social network sites. New York: Routledge, pp. 39-58.

Bart Cammaerts, Alice Mattoni and Patrick McCurdy (editors), 2013. Mediation and protest movements. Bristol: Intellect.

Nico Carpentier, 2011. Media and participation: A site of ideologicaldemocratic struggle. Bristol: Intellect.

Manuel Castells, 2015. Networks of outrage and hope: Social movements in the Internet age. Second edition. Cambridge: Polity Press.

Isidoropaolo Casteltrione, 2015. "The Internet, social networking Web sites and political participation research: Assumptions and contradictory evidence," First Monday, volume 20, number 3, at http://firstmonday.org/article/view/5462/4403, accessed 13 August 2015. doi: http://dx.doi.org/10.5210/fm.v20i3.5462, accessed 1 January 2016.

Ronika Chakrabarti and Pierre Berthon, 2012. "Gift giving and social emotions: experience as content," Journal of Public Affairs, volume 12, number 2, pp. 154-161.

doi: http://dx.doi.org/10.1002/pa.1417, accessed 1 January 2016. 
Cheezburger, Inc., 2013. "Downfall/Hitler reacts," Know Your Meme, at http://knowyourmeme.com/memes/downfall-hitler-reacts, accessed 13 August 2015

Henrik Serup Christensen, 2011. "Political activities on the Internet: Slacktivism or political participation by other means?" First Monday, volume 16, number 2, at http://firstmonday.org/article/view/3336/2767, accessed 24 March 2014

doi: http://dx.doi.org/10.5210/fm.v16i2.3336, accessed 1 January 2016.

Peter Dahlgren, 2005. "The Internet, public spheres, and political communication: Dispersion and deliberation," Political Communication, volume 22 , number 2 , pp. 147-162.

doi: http://dx.doi.org/10.1080/10584600590933160, accessed 1 January 2016

Donatella Della Porta and Mario Diani, 2006. Social movements: An introduction. Second edition. Malden, Mass.: Blackwell.

Nahed Eltantawy and Julie B. Wiest, 2011. "The Arab Spring: Social media in the Egyptian Revolution: Reconsidering resource mobilization theory," International Journal of Communication, volume 5, pp. 1,207-1,224, at http://ijoc.org/index.php/ijoc/article/view/1242, accessed 1 January 2016.

Bernard Enjolras, Kari Steen-Johnsen and Dag Wollebæk, 2012. "Social media and mobilization to offline demonstrations: Transcending participatory divides?" New Media \& Society, volume 15, number 6, pp. 890-908.

doi: http://dx.doi.org/10.1177/1461444812462844, accessed 1 January 2016.

Focus, 2013. "Volby do Poslanecké sněmovny Parlamentu ČR: Povolební analýza," at

http://img.ct24.cz/multimedia/documents/53/5202/520131.pdf, accessed 1 January 2016

Venelin I. Ganev, 2014. "Bulgaria's year of civic anger," Journal of Democracy, volume 25, number 1, pp. 33-45.

doi: http://dx.doi.org/10.1353/iod.2014.0006, accessed 1 January 2016.

William W. Gaver, 1991. "Technology affordances," CHI '91: Proceedings of the SIGCHI Conference on Human Factors in Computing Systems, pp. 79-84.

doi: http://dx.doi.org/10.1145/108844.108856, accessed 1 January 2016.

Paolo Gerbaudo, 2012. Tweets and the streets: Social media and contemporary activism. London: Pluto Press.

Jeff Goodwin, James M. Jasper and Francesca Polletta (editors), 2001. Passionate politics: Emotions and social movements. Chicago: University of Chicago Press.

Julian McAllister Groves, 2001. "Animal rights and the politics of emotion: Folk constructions of emotion in the animal rights movement," In: Jeff Goodwin, James M. Jasper and Francesca Polletta (editors). Passionate politics: Emotions and social movements, Chicago: University of Chicago Press, pp. 212-229.

Anatoliy Gruzd and Ksenia Tsyganova, 2015. "Information wars and online activism during the 2013/2014 crisis in Ukraine: Examining the social structures of pro- and anti-Maidan groups," Policy \& Internet, volume 7 , number 2 , pp. 121-158

doi: http://dx.doi.org/10.1002/poi3.91, accessed 1 January 2016.

Jürgen Habermas, 1989. The structural transformation of the public sphere: An inquiry into a category of bourgeois society. Translated by Thomas Burger with the assistance of Frederick Lawrence. Cambridge, Mass.: MIT Press.

Summer Harlow, 2013. "It was a 'Facebook revolution': Exploring the meme-like spread of narratives during the Egyptian protests," Revista de Communicación, volume 12 , pp. 59-82, at http://udep.edu.pe/comunicacion/rcom/en/articulos/2013/Art059082.html, accessed 1 January 2016.

Tim Highfield, 2015. "Tweeted joke lifespans and appropriated punch lines: Practices around topical humor on social media," International Journal of Communication, volume 9, pp. 2,713-2,734, at http://ijoc.org/index.php/ijoc/article/view/3611, accessed 1 January 2016

Amber Willard Hinsley and Hyunmin Lee, 2015. "\#Ferguson strategic messaging: How local journalists and activists used Twitter," \#ISOJ, volume 5 , number 1 , at https://isojiournal.wordpress.com/2015/04/15/ferguson-strategicmessaging-how-local-journalists-and-activists-used-twitter-as-acommunication-tool/, accessed 11 June 2015 .

James M. Jasper, 2011. "Emotions and social movements: Twenty years of theory and research," Annual Review of Sociology, volume 37, pp. 
285-303

doi: http://dx.doi.org/10.1146/annurev-soc-081309-150015, accessed 1 January 2016.

James M. Jasper, 1998. "The emotions of protest: Affective and reactive emotions in and around social movements," Sociological Forum, volume 13, number 3, pp. 397-424.

Henry Jenkins, 2006. Convergence culture: Where old and new media collide. New York: New York University Press.

Cat Jones, 2015. "Slacktivism and the social benefits of social video: Sharing a video to 'help' a cause," First Monday, volume 20, number 5, at http://firstmonday.orq/article/view/5855/4458, accessed 13 August 2015.

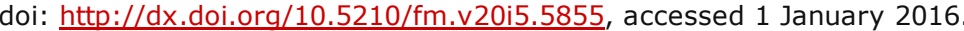

Andreas Jungherr, 2012. "The German federal election of 2009: The challenge of participatory cultures in political campaigns," Transformative Works and Cultures, volume 5, number 10, at http://journal.transformativeworks.org/index.php/twc/article/view/310/288, accessed 1 January 2016.

Anastasia Kavada, 2014. "Social media and decentralised protest movements: The case of Occupy London," ECPR, at http://www.ecpr.eu/Events/PaperDetails.aspx? PaperID =21786\&EventID =14, accessed 5 September 2014 .

Anastasia Kavada, 2013. "Internet cultures and protest movements: The cultural links between strategy, organizing and online communication," In: Bart Cammaerts, Alice Mattoni and Patrick McCurdy (editors). Mediation and protest movements. Bristol: Intellect, pp. 75-94.

Theodore D. Kemper, 2001. "A structural approach to social movement emotions," In: Jeff Goodwin, James M. Jasper and Francesca Polletta (editors). Passionate politics: Emotions and social movements. Chicago: University of Chicago Press, pp. 58-73.

Habibul Haque Khondker, 2011. "Role of the new media in the Arab Spring," Globalizations, volume 8, number 5, pp. 675-679. doi: http://dx.doi.org/10.1080/14747731.2011.621287, accessed 1 January 2016

Gustave Le Bon, 2001. The crowd: A study of the popular mind. Mineola, N.Y.: Dover.

Marcin Lewiński, 2010. "Internet political discussion forums as an argumentative activity type: A pragma-dialectical analysis of online forms of strategic manoeuvring in reacting critically" Ph.D. thesis, Universiteit van Amsterdam, at http://dare.uva.nl/document/2/77136, accessed 13 August 2015.

Ryan M. Milner, 2013. "Pop polyvocality: Internet memes, public participation, and the Occupy Wall Street movement," International Journal of Communication, volume 7, pp. 2,357-2,390, at http://ijoc.org/index.php/ijoc/article/view/1949, accessed 1 January 2016.

Evgeny Morozov, 2009. "Foreign policy: Brave new world Of slacktivism," NPR.org (19 May), at http://www.npr.org/templates/story/story.php? storyId $=104302141$, accessed 6 January 2015

Pippa Norris, 2000. A virtuous circle: Political communications in postindustrial societies. Cambridge: Cambridge University Press.

Olga Onuch, 2015. "'Facebook helped me do it': Understanding the EuroMaidan protester 'tool-kit'," Studies in Ethnicity and Nationalism, volume 15 , number 1 , pp. $170-184$

doi: http://dx.doi.org/10.1111/sena.12129, accessed 1 January 2016.

Andrew M. Peck, 2014. "A laugh riot: Photoshopping as vernacular discursive practice," International Journal of Communication, volume 8 , pp. 1,638-1,662, at http://ijoc.org/index.php/ijoc/article/view/2692, accessed 1 January 2016.

Thomas Poell and José van Dijck, 2015. "Social media and activist communication," In: Chris Atton (editor). Routledge companion to alternative and community media. London: Routledge, pp. 527-537, and at http://dare.uva.nl/document/2/162543, accessed 13 August 2015.

Anabel Quan-Haase and Alyson L. Young, 2010. "Uses and gratifications of social media: A comparison of Facebook and instant messaging," Bulletin of Science, Technology \& Society, volume 30, number 5, pp. 350-361. doi: http://dx.doi.org/10.1177/0270467610380009, accessed 1 January 2016.

Bernhard Rieder, 2013. "Studying Facebook via data extraction: The Netvizz application," WebSci '13: Proceedings of the Fifth Annual ACM Web Science Conference, pp. 346-355. doi: http://dx.doi.org/10.1145/2464464.2464475, accessed 1 January 2016 
Carlos Ruiz, David Domingo, Josep Lluís Micó, Javier Díaz-Noci, Koldo Meso and Pere Masip, 2011. "Public sphere 2.0? The democratic qualities of citizen debates in online newspapers," International Journal of Press/Politics, volume 16, number 4, pp. 463-487.

doi: http://dx.doi.org/10.1177/1940161211415849, accessed 1 January 2016.

Sebastian Sevignani, Robert Prey, Marisol Sandoval, Thomas Allmer, Jernej A. Prodnik and Verena Kreilinger, 2014. "Critical studies of contemporary informational capitalism: The perspective of emerging scholars," In: Christian Fuchs and Marisol Sandoval (editors). Critique, social media and the information society. New York: Routledge, pp. 7690.

Limor Shifman, 2011. "An anatomy of a YouTube meme," New Media \& Society, volume 14, number 2, pp. 187-203. doi: http://dx.doi.org/10.1177/1461444811412160, accessed 1 January 2016.

Smíchov, 2013. "Internet humor neztrácí: Povolební situace ve fotomontážích," TV NOVA - Smíchov, at http://smichov.nova.cz/clanek/foto/internet-humor-neztraci-povolebnisituace-ve-fotomontazich.html, accessed 23 July 2015.

Andrew D. Smock, Nicole B. Ellison, Cliff Lampe and Donghee Yvette Wohn, 2011. "Facebook as a toolkit: A uses and gratification approach to unbundling feature use," Computers in Human Behavior, volume 27, number 6 , pp. 2,322-2,329.

doi: http://dx.doi.org/10.1016/i.chb.2011.07.011, accessed 1 January 2016.

David A. Snow, E. Burke Rochford, Jr., Steven K. Worden and Robert D. Benford, 1986. "Frame alignment processes, micromobilization, and movement participation," American Sociological Review, volume 51 number 4 , pp. 464-481.

doi: http://dx.doi.org/10.2307/2095581, accessed 1 January 2016.

Václav Štětka, 2014. "Facebook jako prostředek mobilizace v parlamentních volbách 2013," POLCORE - Political Communication Research Group (13 May), at http://polcore.fsv.cuni.cz/facebook-jakoprostredek-mobilizace-v-parlamentnich-volbach-2013/\#more-284, accessed 19 August 2015

Václav Štětka and Jaromír Mazák, 2014. "Whither slacktivism? Political engagement and social media use in the 2013 Czech parliamentary elections," Cyberpsychology: Journal of Psychosocial Research on Cyberspace, volume 8, number 3 , article 1 , at http://www.cyberpsychology.eu/view.php?cisloclanku=2014100102 accessed: 18 November 2014. doi: http://dx.doi.org/10.5817/CP2014-3-7, accessed 1 January 2016.

Mariyan Tomov and Lilia Raycheva, 2015. "The Facebook image of the 2013/2014 social protests in Bulgaria," In: Bogusława Dobek-Ostrowska and Michał Głowacki (editors). Democracy and media in Central and Eastern Europe 25 years on. Oxford: Peter Lang.

Natália Vítková, 2013. "Pinocchio, Švejk, Iživý medvěd od Kolína. Lidé vtipkují na Haškưv účet," iDNES.cz, at http://zpravy.idnes.cz/hasekrozsiril-ceskou-slovni-zasobu-dvl-/domaci.aspx? c=A131030 144959 domaci nat, accessed 23 July 2015.

Martin Vrba, 2015. E-mail interview with Martin Vrba, spokesman of the 'I Want Bohuslav Sobotka, not Michal Hašek' initiative.

Zheng Wang, John M. Tchernev and Tyler Solloway, 2012. "A dynamic longitudinal examination of social media use, needs, and gratifications among college students," Computers in Human Behavior, volume 28, number 5 , pp. 1,829-1,839.

doi: http://dx.doi.org/10.1016/j.chb.2012.05.001, accessed 1 January 2016.

Lori M. Weber, Alysha Loumakis and James Bergman, 2003. "Who participates and why? An analysis of citizens on the Internet and the mass public," Social Science Computer Review, volume 21, number 1, pp. $26-42$.

doi: http://dx.doi.org/10.1177/0894439302238969, accessed 1 January 2016.

Patrick Weber, 2014. "Discussions in the comments section: Factors influencing participation and interactivity in online newspapers' reader comments," New Media \& Society, volume 16, number 6, pp. 941-957. doi: http://dx.doi.org/10.1177/1461444813495165, accessed 1 January 2016.

Assa Wettergren, 2005. "Mobilization and the moral shock: Adbusters Media Foundation," In: Helena Flam and Debra King (editors). Emotions and social movements. New York: Routledge, pp. 99-118.

Scott Wright and John Street, 2007. "Democracy, deliberation and design: The case of online discussion forums," New Media \& Society, volume 9, number 5, pp. 849-869. 
doi: http://dx.doi.org/10.1177/1461444807081230, accessed 1 January 2016.

\section{Editorial history}

Received 27 November 2015; revised 3 January 2016; accepted 4 January 2016.

\section{(ब) $\odot \odot$}

Toto dílo podléhá licenci Creative Commons Uvedte původ-Neužívejte dílo komerčně-Zachovejte licenci 4.0 Mezinárodní License.

The coup that flopped: Facebook as a platform for emotional protest by Jaroslav Švelch and Václav Štětka.

First Monday, Volume 21, Number 1 - 4 January 2016

http://firstmonday.org/ojs/index.php/fm/article/view/6333/5188

doi: http://dx.doi.org/10.5210/fm.v21i1.6333

A Great Cities Initiative of the University of Illinois at Chicago University Library.

(c) First Monday, 1995-2016. 